\title{
COMMENTS
}

\section{CRIMINALIZATION AND PROSECUTION OF HUMAN TRAFFICKING IN ETHIOPIA: ASSESSING THE LEGAL FRAMEWORK IN LIGHT OF INTERNATIONAL STANDARDS}

\author{
ZELALEM SHIFERAW WOLDEMICHAEL, \\ Jimma University (Jimma, Ethiopia)
}

DOI: $10.21684 / 2412-2343-2017-4-3-110-135$

As is the case in many countries, in Ethiopia human trafficking causes multi-dimensional harmful consequences on individuals. With a view to addressing the problem, in 2012 Ethiopia acceded to the Protocol to Prevent, Suppress and Punish Trafficking in Persons, Especially Women and Children, supplementing the United Nations Convention against Transnational Organized Crime. For the purpose of translating the requirements of the UN Trafficking Protocol into reality, the government has taken various steps including legislative measures. Proclamation No. 909/2015 (Prevention and Suppression of Trafficking in Persons and Smuggling of Migrants Proclamation) is the most recent law adopted to deal with smuggling of migrants and human trafficking. The Proclamation comprises four key aspects: criminalization and prosecution; prevention; protection, rehabilitation and compensation; and cooperation. This article critically examines whether the criminalization and prosecution aspect of the Proclamation complies with international standards.

Keywords: exploitation; human trafficking; Trafficking and Smuggling Proclamation; UN Trafficking Protocol; vulnerability.

Recommended citation: Zelalem Shiferaw Woldemichael, Criminalization and Prosecution of Human Trafficking in Ethiopia: Assessing the Legal Framework in Light of International Standards, 4(3) BRICS Law Journal 110-135 (2017). 


\section{Introduction}

Human trafficking is a growing challenge affecting virtually all countries.' Between 2010 and 2012, victims of human trafficking with 152 different citizenships were identified, according to a 2014 global report produced by the United Nations Office on Drugs and Crime (UNODC). ${ }^{2}$ The report further noted that at least 510 trafficking flows exist worldwide. ${ }^{3}$ Research conducted in 2006 under the sponsorship of the U.S. government revealed that approximately 800,000 people are trafficked across national borders annually, excluding the millions trafficked within their own countries. ${ }^{4}$ Human trafficking is a lucrative business for traffickers enabling them to gain an estimated US\$32 billion annually.

Between 1996 and 1997, the United Nations Special Rapporteur on Violence against Women collected information on violence against women, including trafficking. ${ }^{6}$ The subsequent report highlighted that because trafficking involves cross-border movement it is an issue that should be addressed by international standards and consensus.' It was agreed that adopting an international treaty to supplement the United Nations Convention on Transnational Organized Crime (UNTOC) is essential for addressing the problem. ${ }^{8}$ The UN Trafficking Protocol is a response towards that end.

Human trafficking is a serious problem in Ethiopia. As the U.S. State Department in its 2015 report presented, Ethiopia is a source and, to a lesser extent, destination and transit country for men, women and children subjected to forced labor and sex trafficking. ${ }^{9}$ On top of this, as the available research on the subject indicates, both in-country trafficking (the trafficking of women, children or men from the rural areas of Ethiopia to the relatively more affluent towns and cities) and external trafficking (the trafficking of women, children or men from Ethiopia to other states such as Middle East countries) are prevalent. ${ }^{10}$

UNODC, Global Report on Trafficking in Persons (2016), at 5.

2 Seeid.

3 See id.

4 UNODC, Human Trafficking: An Overview (2008), at 6.

5 UNODC, Human Trafficking: Organized Crime and the Multibillion Dollar Sale of People (Sep. 4, 2017), available at http://www.unodc.org/unodc/en/frontpage/2012/July/human-trafficking_-organizedcrime-and-the-multibillion-dollar-sale-of-people.html.

6 The Advocates for Human Rights, Trafficking in Women: Law and Policy, Stop Violence against Women, a Project of the Advocates for Human Rights (Sep. 4, 2017), available at http://www.stopvaw.org/Traf ficking_Law_and_Policy.html.

seeid.

8 See the last paragraph of the Preamble to the UN Convention against Transnational Organized Crime.

9 U.S. Department of State, Trafficking in Persons Report 2015 - Country Narratives - Ethiopia (2015), at 15.

10 Yoseph Endeshaw et al., Assessment of Trafficking in Women and Children in and from Ethiopia (2010), at 5 (Sep. 4, 2017), available at https://pdfs.semanticscholar.org/1c43/16956c226fa5a14f3c fee78498d7bc5f4566.pdf. 
Despite the dearth of concrete data evidencing the actual number of victims of the practice, scattered data gathered by the government of Ethiopia, various organizations and individual researchers demonstrate that large numbers of individuals are subjected to human trafficking. The U.S. Department of State report referred to above indicates that officials report up to 1,500 Ethiopians depart daily as part of the legal migration process." The report further elucidates that many young Ethiopians transit through Djibouti, Egypt, Somalia, Sudan or Kenya in search of jobs in the Middle East in which case some become stranded, exploited or subjected to detention, extortion and severe abuse on the way to their final destination. ${ }^{12}$

The International Organization for Migration (IOM) also reported that in the years 2011 and 2012 as many as 109,611 individuals illegally entered Yemen seeking better employment opportunities. ${ }^{13}$ Even though the data fail to indicate the consequences of such illegal crossing of boarders on the migrants, it is not difficult to speculate that the process might have subjected them to illegal trafficking. Very recently it was reported that at least 2,650 Ethiopians from the Hadiya Zone (in southern Ethiopia) have lost their lives as the result of human trafficking since $2013 .{ }^{14}$ In addition, thousands more are unaccounted for or have suffered physical harm. ${ }^{15}$

The available studies analyzing the number of individuals subjected to human trafficking generally emphasize external trafficking, with very limited information concerning internal trafficking. This should not be taken to mean that the problem is not pressing. Though disorganized and incomplete, the existing research implies that in-country trafficking persists in the country. The IOM, for example, found that there is widespread in-country trafficking of women and children from rural areas to urban centers. ${ }^{16}$

Predominantly, women and children are trafficked internally for the purpose of domestic labor, as weavers in the traditional weaving industry and as prostitutes in major regional towns and Addis Ababa. ${ }^{17}$ The trafficking of children for labor and begging also takes place. ${ }^{18}$ Wagayehu Tufa likewise has observed that in-country trafficking victims face multiple human rights violations including labor exploitation, and physical, emotional and sexual abuse. ${ }^{19}$

11 U.S. Department of State, supra note 9, at 157

12 See id.

13 National Council of the FDRE on the Prevention of Human Trafficking, Strategic Plan (2015-2019), at 1.

14 The Ugly Face of Human Trafficking in Ethiopia, Walta Info (Sep. 4, 2017), available at www.waltainfo.com.

15 See id.

16 Endeshaw et al., supra note 10, at 5.

17 See id.

18 See id.

19 Wagayehu Tufa, Socio-Economic Impacts of Human Trafficking in Ethiopia the Case of Bati Town, Oromo Administration Zone, Amhara Regional State (October 2014) (unpublished MA Thesis, Haramaya University). 
Victims of external trafficking also sustain serious human rights violations. Selamawit B. Woldemichael in her research notes that children who migrate to the Middle East face serious labor exploitation and other human rights violations. ${ }^{20}$ The plight of these individuals is exacerbated by the fact that most of them do not fulfill the minimum age requirements to engage in work. ${ }^{21}$ Khaled Ali Beydoun has identified that large numbers of Ethiopian women have been trafficked lured by false promises of good jobs, high salaries and a comfortable life. Most of these women end up as modem-day slaves. ${ }^{22}$ He noted:

The recruitment process can involve a number of dangers and risks for migrants, especially for women who lack access to reliable and timely information. The dangers and risks they face include: overcharging of fees; debt bondage; falsification of documents; deception with regard to the nature and conditions of employment, including contract substitution and the mail-order bride trade; exploitation and abuse while waiting for the job to materialize or to be sent abroad; lack of preparation for employment abroad, including lack of pre departure training; forced/coerced recruitment, including being kidnapped or sold to illegal recruiters or traffickers; hazardous journey to the country of destination.

Ethiopia ratified the UNTOC and its supplementing protocols including the UN Trafficking Protocol. ${ }^{23}$ To give effect to the treaties, the government has taken various steps including administrative and legislative measures. The Trafficking and Smuggling Proclamation was adopted to address the problem of human trafficking in a comprehensive manner. The Proclamation incorporates four key aspects that help to deal with all forms of exploitation that human trafficking brings about. These are: i. Criminalization and Prosecution; ii. Prevention; iii. Protection, rehabilitation and compensation; and iv. Cooperation. It goes without saying that in order to effectively address human trafficking, it is important to have an adequate legal protection framework, compliant with international standards. This article assesses the Criminalization and Prosecution aspect of the Proclamation in light of international standards.

Selamawit B. Woldemichael, The Vulnerability of Ethiopian Women and Girls: The Case of Domestic Workers in Saudi Arabia and Kuwait (June 2013) (unpublished MA Thesis, Uppsala University), at 41. See id.

22 Khaled Ali Beydoun, The Trafficking of Ethiopian Domestic Workers into Lebanon: Navigating through a Novel Passage, 24(3) Berkeley Journal of International Law 1009, 1022 (2006).

23 Status of adherence to the United Nations Convention against Transnational Organized Crime and the Protocols thereto as at 10 September 2014 (CTOC/COP/2014/CRP.1). 


\section{International Legal Framework for Addressing Human Trafficking}

The first legal instrument adopted at the international level to combat trafficking was the 1904 International Agreement for Suppression of the White Slave Traffic. ${ }^{24}$ This binding treaty was adopted by thirteen European states to halt the sale of women into prostitution. ${ }^{25}$ Regrettably, the instrument did not bring the intended result of suppression of trafficking for sexual exploitation due to the absence of an organized enforcement mechanism. ${ }^{26}$ This palpable weakness in the agreement triggered the League of Nations to adopt the International Convention for the Suppression of White Slave Traffic in 1910. ${ }^{27}$ As Corin Morcom and Andreas Schloenhardt have emphasized, both the 1904 Agreement and the 1910 Convention are gender- and race-based since they do not apply to males or to non-Caucasian women and girls. ${ }^{28}$

The International Convention for the Suppression of the Traffic in Women adopted in 1921 omitted specific reference to women and race. The term "white slave" was dropped and the Convention underscored that both women and children of any race can be subject to trafficking. ${ }^{29}$

In 1933, another convention, the International Convention for the Suppression of the Traffic in Women of Full Age, was adopted. Like the 1921 Convention, this instrument enjoins States Parties to criminalize acts of trafficking in human beings. ${ }^{30}$ It extended the punishable acts of trafficking to include "attempted offences" and "preparatory acts within the legal limits."

The notable shortcoming of the White Slave Traffic Convention is that it considers only the recruitment and transportation process, and leaves the regulation of prostitution to be dealt with by nations domestically. ${ }^{32}$ This modality was considered by the "abolitionist movement" as ineffective in addressing human trafficking. ${ }^{33}$

24 International Agreement for the Suppression of the White Slave Traffic, 18 May 1904, entered into force 18 July 1905.

25 Woldemichael, supra note 20.

26 Rashida Manjoo, Trafficking of Women: Norms, Realities, and Challenges, 7(1) Albany Government Law Review 5, 14 (2014).

27 International Convention for the Suppression of the White Slave Traffic, 4 May 1910.

28 Corin Morcom \& Andreas Schloenhardt, All about Sex?!: The Evolution of Trafficking in Persons in International Law (March 2011), at 13 (Sep. 4, 2017), available at https://law.uq.edu.au/files/4311/ Evolution-of-Int-Law-relating-to-Trafficking-in-Persons.pdf.

29 Tom Obokata, Trafficking of Human Beings from a Human Rights Perspective: Towards a Holistic Approach 16 (Leiden: Martinus Nijhoff, 2006).

30 See Art. 1 of the Convention.

31 See id.

32 Morcom \& Schloenhardt, supra note 28, at 14.

33 See id. 
The movement strongly advocated that prostitution was a key impetus to women trafficking, and hence should not be treated as something that falls within the domestic sphere. ${ }^{34}$

In 1937, the League of Nations prepared a draft convention accommodating the "abolitionist approach." ${ }^{135}$ The convention sought to draw concerted effort to abolish licensed houses and punish any person managing a brothel or exploiting the prostitution of others. The draft did not come to its final stage, owing to the outbreak of the Second World War. ${ }^{36}$ The 1947 Protocol amending the International Convention for the Suppression of Traffic in Women and Children, and the International Convention for the Suppression of Traffic in Women of Full Age also brought no significant improvement to the amended instruments in terms of elaborating the definition and setting mechanisms of addressing the problem of human trafficking.

The 1949 Convention for the Suppression of the Traffic in Persons and of the Exploitation of the Prostitution of Others ${ }^{37}$ consolidated earlier conventions and upheld the abolitionist approach by promoting a policy of preventing prostitution and rehabilitating its victims. ${ }^{38}$ This instrument remained the major international treaty on the subject of trafficking for the next five decades. ${ }^{39}$ Under Art. 2, the Convention explicitly requires States Parties to punish any person who keeps or manages or knowingly finances or takes part in the financing of a brothel. It also enjoined States Parties to encourage, through their public or educational, health, social, economic and other related services, measures for the prevention of prostitution and for the rehabilitation and social adjustment of the victims of prostitution and of the traffic. ${ }^{40}$

Though the 1949 Convention brought important improvements in dealing with human trafficking through upholding the abolitionist approach, it was fraught with defects that hindered its effectiveness. The instrument, for instance, fails to take into account other areas of exploitation beyond the sex industry. ${ }^{41}$ It also lacks

34 See Morcom \& Schloenhardt, supra note 28 , at 14.

35 See para. 2 of the Preamble to the 1949 Convention for the Suppression of the Traffic in Persons and of the Exploitation of the Prostitution of Others.

36 See id.

37 The Convention was adopted by the UN General Assembly in December 1949 and entered into force on 25 July 1951.

38 See id.

39 OHCHR, Recommended Principles and Guidelines on Human Rights and Human Trafficking (2010), at 19 (Sep. 4, 2017), available at http://www.ohchr.org/Documents/Publications/Commentary_ Human_Trafficking_en.pdf.

40 See Art. 16 of the Convention.

41 Silvia Scarpa, Trafficking in Human Beings: Modern Slavery 52 (Oxford: Oxford University Press, 2008). 
a comprehensive definition of human trafficking. Malka Marcovich has further pointed out that the Convention was established without a strong monitoring mechanism. ${ }^{42}$ Even though Art. 2 of the Convention requires States Parties to communicate to the UN Secretary-General their laws and regulations relating to the Convention, as well as all measures taken by them concerning its application, and the obligation of the Secretary-General to publish "periodically the information received," these provisions have not been followed. ${ }^{43}$ Thus many states that have signed the Convention are not adhering to its provisions, and some have even changed their laws in opposition to the principles of the Convention. ${ }^{44}$ The ineffectiveness of the Convention in tackling the problem of illegal trafficking in persons ultimately necessitated the adoption of a more comprehensive and inclusive Convention. ${ }^{45}$

The UN Trafficking Protocol was born from a meeting of an intergovernmental group of experts established by the UN General Assembly in 1998. During the Seventh Session of the Commission on Crime Prevention and Criminal Justice that year, Argentina suggested drafting a new convention against trafficking in minors. ${ }^{46}$ On the suggestion of Greece, Member States decided to expand the scope of the instrument to include all forms of trafficking in persons by giving special attention to women and children, given their specific vulnerability to this form of crime. ${ }^{47}$

The UNTrafficking Protocol represents an effort to harmonize global understanding around the concept of trafficking in persons. ${ }^{48}$ It aims to confront organized crime networks and combat the trade in human beings and transnational prostitution. ${ }^{49}$ Before its adoption, no international instrument provided this comprehensive and international approach by targeting countries of origin, transit and destination. ${ }^{50}$

42 Malka Marcovich, Guide to the UN Convention of 2 December 1949 for the Suppression of the Traffic in Persons and of the Exploitation of the Prostitution of Others (Sep. 4, 2017), available at http://www. catwinternational.org/Content/Images/Article/88/attachment.pdf.

43 See id.

44 See id.

45 Scarpa 2008, at 55.

46 Anne Gallagher, Human Rights and the New UN Protocols on Trafficking and Migrant Smuggling: A Preliminary Analysis, 23 Human Rights Quarterly 975 (2001).

47 Natalia Ollus, The United Nations Protocol to Prevent, Suppress and Punish Trafficking in Persons, Especially Women and Children: A Tool for Criminal Justice Personnel, at 20 (Sep. 4, 2017), available at http://www. unafei.or.jp/english/pdf/RS_No62/No62_06VE_Ollus1.pdf.

48 UNODC, Toolkit to Combat Trafficking in Persons (2008), at 1 (Sep. 4, 2017), available at https://www. unodc.org/documents/human-trafficking/HT_Toolkit08_English.pdf.

49 Janice Raymond, Guide to The New UN Trafficking Protocol (Sep. 4, 2017), available at http://www. catwinternational.org/Content/Images/Article/83/attachment.pdf.

50 Mohamed Y. Mattar, Trafficking in Persons, Especially Women and Children, in Countries of the Middle East: The Scope of the Problem and the Appropriate Legislative Responses, 26 Fordham International Law Journal 721, 722 (2002). 
Moreover, the Protocol reaches beyond sexual exploitation to cover all forms of trafficking in men, women and children. ${ }^{51}$

Article 2 of the Protocol outlines that the purposes of the instrument are:

i. To prevent and combat trafficking in persons, paying particular attention to women and children;

ii. To protect and assist the victims of such trafficking, with full respect for their human rights; and

iii. To promote cooperation among States Parties in order to meet those objectives.

The Protocol is applauded for introducing a clear and internationally agreed definition of trafficking in persons. ${ }^{52}$ International instruments in force prior to it did not define "trafficking in human beings" though various international legal documents used the term "trafficking in women." ${ }^{\prime \prime 3}$ In fact, Natalia Ollus has noted that the definition was the most controversial part of the Protocol during negotiations. ${ }^{54}$ As the travaux préparatoires of the instrument indicates, for example, whether the Protocol should contain definitions referring to specific groups such as "children" or "women" was debated..$^{55}$ In the end, the specific reference to "children" or "women" was not favored; the majority of the delegations suggested keeping the definitions general, defining the term "trafficking in persons" rather than the terms "trafficking in children" or "trafficking in women."56

Article 3 of the Protocol provides the definition of trafficking in persons. It reads:

(a) "Trafficking in persons" shall mean the recruitment, transportation, transfer, harboring or receipt of persons, by means of the threat or use of force or other forms of coercion, of abduction, of fraud, of deception, of the abuse of power or of a position of vulnerability or of the giving or receiving of

51 Andreas Schloenhardt \& Ellen Bevan, To Ratify or Not to Ratify? Exploring the Barriers to Wider Ratification of the Trafficking in Persons Protocol, 9 New Zealand Yearbook of International Law 161 (2011).

UNODC, Legislative Guides for the Implementation of the United Nations Convention against Transnational Organized Crime and The Protocols Thereto (2004), at 267 (Sep. 4, 2017), available at https://www.unodc.org/pdf/crime/legislative_guides/Legislative\%20guides_Full\%20version.pdf.

53 International Centre for Migration Policy Development, Legislation and the Situation Concerning Trafficking in Human Beings for the Purpose of Sexual Exploitation in EU Member States (2009), at 21 (Sep. 4, 2017), available at https://ec.europa.eu/home-affairs/sites/homeaffairs/files/doc_centre/ crime/docs/evaluation_eu_ms_thb_legislation_en.pdf.

Ollus, supra note 47 , at 22 .

55 See id.

56 UNODC, Travaux Préparatoires of the Negotiations for the Elaboration of the United Nations Convention against Transnational Organized Crime and the Protocols thereto (2006) (Sep. 4, 2017), available at https://www.unodc.org/pdf/ctoccop_2006/04-60074_ebook-e.pdf. 
payments or benefits to achieve the consent of a person having control over another person, for the purpose of exploitation. Exploitation shall include, at a minimum, the exploitation of the prostitution of others or other forms of sexual exploitation, forced labor or services, slavery or practices similar to slavery, servitude or the removal of organs;

(b) The consent of a victim of trafficking in persons to the intended exploitation set forth in subparagraph (a) of this article shall be irrelevant where any of the means set forth in subparagraph (a) have been used;

(c) The recruitment, transportation, transfer, harboring or receipt of a child for the purpose of exploitation shall be considered "trafficking in persons" even if this does not involve any of the means set forth in subparagraph (a) of this article;

(d) "Child" shall mean any person under eighteen years of age.

The definition produced above has three elements: i. Act (recruitment, receipt, transport, transfer and harboring), ii. Means (force, deception, coercion, fraud, abuse of power or of a position of vulnerability, payment or receipt of a benefit to a person with control of another) and iii. Purpose (exploitation).

The provision, as one may note, makes the consent of a victim irrelevant if any of the means set forth in subparagraph (a) have been used. Consent is also irrelevant if the trafficking victim is a child. As long as an act of recruitment, transportation, transfer, harboring or receipt of a child takes place for the purpose of inflicting exploitation, an act will be dubbed trafficking in persons despite the process not involving threat, force, coercion, abduction, fraud, deception, abuse of power, the giving or receiving of payments or benefits to achieve the consent of a person having control over the child. The Protocol defines a child as any person less than eighteen years of age. Unlike the Convention on the Rights of the Child (CRC), the Protocol does not give discretion to States Parties to determine conditions under which a person below the age of eighteen may be considered to have attained majority. ${ }^{57}$

The term "at a minimum" in the definition outlined above offers the possibility of including other forms of exploitation in addition to sexual exploitation, forced labor or services, slavery or practices similar to slavery, servitude or the removal of organs mentioned in the provision. The Protocol, hence, accommodates possible - known or still unknown - forms of exploitation. ${ }^{58}$ It is noteworthy that earlier drafts contained definitions for sexual exploitation, forced labor, slavery and Servitude. ${ }^{59}$ The final text omitted such definitions, leaving them for ratifying States to deal with.

57 The CRC, under Art. 1, sets out the definition of a child. It provides:" $[A]$ child means every human being below the age of eighteen years unless under the law applicable to the child, majority is attained earlier."

58 Kristina Touzenis, Trafficking in Human Beings: Human Rights and Transnational Criminal Law, Developments in Law and Practices 38 (Paris: UNESCO, 2010).

59 UNODC, supra note 56 , at 341-344. 
The Protocol is meant to apply to the prevention, investigation and prosecution of offenses established in accordance with its Art. 5, where the offenses are transnational in nature and involve an organized criminal group as well as to the protection of victims of such offenses..$^{60}$ As authorities including the Economic and Social Commission for Asia and the Pacific rightly argue, however, states should not limit application of the instrument to trafficking in persons that is transnational and involves an organized criminal group since trafficking in persons also occurs within states' borders. ${ }^{61}$ The United Nations Convention against Transnational Organized Crime maps out that crimes committed within the domestic jurisdiction of a single state may be considered as a transnational organized crime. ${ }^{62}$

The decisive steps that States Parties should take to implement the Protocol include criminalization of human trafficking. This is expected to be done, as indicated under Art. 5, by adopting legislative and other measures as may be necessary. Criminalization of human trafficking is required to be made taking into account the definition offered for human trafficking under Art. 3 of the Protocol. The Protocol also demands States Parties to criminalize attempting, participating and organizing or directing other persons to commit human trafficking.

The rest of the provisions of the Protocol dwell on issues of "assistance and protection of victims" and "prevention, cooperation and other measures." Protection and assistance of victims of human trafficking includes protecting the privacy and identity of victims, ${ }^{63}$ provision of information on relevant court and administrative proceedings ${ }^{64}$ and provision of physical, psychological and social recovery of victims of the practice. ${ }^{65}$ In addition, the Protocol demands that each State Party should consider adopting legislative or other appropriate measures that permit victims of trafficking in persons to remain in their territory, temporarily or permanently, in appropriate cases. ${ }^{66}$

Prevention, cooperation and other measures introduced in the Protocol require States Parties to establish comprehensive policies, programs and other measures to prevent and combat trafficking in persons, and protect victims of trafficking in

${ }^{60}$ Art. 4 of the UN Trafficking Protocol. This may also be inferred from the fact that the instrument is a protocol supplementing the United Nations Convention against Transnational Organized Crime. Read paras. 5 and 6 of the Preamble to the Protocol.

61 Economic and Social Commission for Asia and the Pacific, Combating Human Trafficking in Asia: A Resource Guide to International and Regional Legal Instruments, Political Commitments and Recommended Practices 100 (New York: United Nations, 2003).

62 See Art. 3(2) of the United Nations Convention against Transnational Organized Crime.

${ }_{63}$ Art. 6(1) of the UN Trafficking Protocol.

${ }^{64}$ Art. 6(2) of the UN Trafficking Protocol.

${ }^{65}$ Art. 6(3) of the UN Trafficking Protocol.

66 Art. 7 of the UN Trafficking Protocol. 
persons, especially women and children, from re-victimization. ${ }^{67}$ Furthermore, the Protocol stresses the importance of strengthening cooperation among the law enforcement, immigration or other relevant authorities of states in accordance with their laws. ${ }^{68}$ In view of regulating cross-border crimes with better efficiency, the Protocol requires States Parties to strengthen border control and prevent unlawful creation and issuance of travel or identity documents. ${ }^{69}$

\section{Legislative Response of the Government of Ethiopia to Address Human Trafficking}

Ethiopia has ratified most of the key international treaties on human trafficking including the UN Convention for the Suppression of the Traffic in Persons and the Exploitation of the Prostitution of Others (1949), the Abolition of Forced Labor Convention (No. 105, 1957) and Convention No. 182 on the Worst forms of Child Labor. ${ }^{70}$ Ethiopia has recently made the landmark decision to become a party to the UN Trafficking Protocol. ${ }^{71}$

The problem of human trafficking is given constitutional recognition in Ethiopia. The Constitution considers human trafficking as a form of inhuman treatment. ${ }^{72}$ Paragraph 2 of Art. 18 reads:

Trafficking in human beings for whatever purpose is prohibited.

This provision was accompanied by the Criminal Code of Ethiopia adopted in 2004. Under Art. 597, it is provided that:

(1) Whoever by violence, threat, deceit, fraud, kidnapping or by the giving of money or other advantage to the person having control over a woman or a child, recruits, receives, hides, transports, exports or imports a woman or a minor for the purpose of forced labor, is punishable with rigorous imprisonment from five years to twenty years, and fine not exceeding fifty thousand Birr.

(2) Whoever knowingly carries off, or transports, whether by land, by sea or by air, the victim mentioned in sub article (1), with the purpose stated therein, or conducts, or aids such traffic, is liable to the penalty prescribed under sub-article (1) above.

\footnotetext{
67 Art. 9 of the UN Trafficking Protocol.

68 Art. 10(1) of the UN Trafficking Protocol.

69 Art. 12 of the UN Trafficking Protocol.

70 Endeshaw et al., supra note 10, at 58.

71 Ethiopia became a party to the UN Trafficking Protocol in June 2012, see CTOC/COP/2014/CRP.1.

72 This can be discerned from the caption of Art. 18, which reads: "Prohibition against Inhuman Treatment."
} 
However, both the Criminal Code and the Federal Democratic Republic of Ethiopia (FDRE) Constitution lack provisions to adequately prevent and combat human trafficking. Specifically, the criminalization of human trafficking is not accompanied by a comprehensive prevention strategy which helps to address the root causes of the problem. Moreover, by focusing on criminalization of the practice, victims are not entitled to receive any assistance. The term "human trafficking" is not defined to include other forms of exploitations. It only covers labor exploitation. Consequently, a person is not liable under the above Article if he uses mechanisms such as violence, threat or deceit, and recruits, receives, hides, transports, exports or imports a woman or a minor for the purpose of "removal of organ" or engaging them in sexual exploitation. This means that the Criminal Code provides limited protection to women and children.

The nature of "consent" and "scope of protection" are the other important notions not properly dealt with under the Criminal Code. The law provides exclusive protection to women and children. Men are not offered protection under this law despite the absence of any reliable information indicating that they are not affected by the problem. ${ }^{73}$ Even in defining the crime, the law deviates from the internationally accepted standard of consent that should be applicable in respect of children. In bringing court action concerning the trafficking of children, the public prosecutor is expected to prove the use of violence, threat, deceit, etc., by the defendant. This is in stark contrast to the UN Trafficking Protocol considered earlier, as this instrument does not expect the public prosecutor to prove the use of violence, threat, deceit, etc., if the victims involved are children. In its current form, the law is not consistent with the FDRE Constitution, which requires that in all actions concerning children, the best interests of the child shall be the primary consideration. ${ }^{74}$

Compared to the grave consequences that human trafficking causes on victims, the penalty prescribed is inappropriate..$^{75}$ The gap between the minimum and maximum penalty to be imposed seems to be too broad. ${ }^{76}$ Unquestionably, this will open the door for potential abuse and misuse of the law, thereby undermining the intended purpose of preventing and combating human trafficking. Furthermore, the Criminal Code has overlooked issues associated with assistance to victims of

73 It is worthwhile to consider that Art. 596(1) of the Criminal Code criminalizes enslavement. This provision regards trafficking in human beings (including trafficking of children, men and women) as a form of enslavement. However, it does not clarify what trafficking in human beings is.

74 See Art. 36 of the FDRE Constitution. The CRC, under Art. 3, also requires that in all actions concerning children, the best interests of the child shall be the primary consideration.

75 UNODC, Strengthening Criminal Justice Responses to Trafficking in Persons and Smuggling of Migrants in Ethiopia and Djibouti (Sep. 4, 2017), available at http://www.unodc.org/brussels/en/ cjr-ethiopia.html.

76 As can be observed from the above-produced provision, the Criminal Code prescribes a minimum of 5 years and maximum of 20 years rigorous imprisonment in addition to fine. 
human trafficking, although this may be beyond the scope of criminal law, as such matters would normally require specific anti-trafficking laws. ${ }^{77}$

The year 2012 represents a milestone in Ethiopia's efforts to combat and prevent human trafficking, as the government acceded to the UN Trafficking Protocol. The treaty requires the government of Ethiopia to give effect to standards entrenched in it through proper mechanisms. This can be drawn from Arts. 5 and 6 of the instrument which enjoin States Parties to adopt legislative and other measures to criminalize human trafficking and provide protection to victims of the practice.

Until August 2015, the government did not put into practice detailed laws to implement the Protocol. It seems clear that given the inadequacy of the existing legal framework to accommodate important elements of the Protocol, comprehensive national legislation is indispensable. ${ }^{78}$ In August 2015, the Trafficking and Smuggling Proclamation was adopted to rectify shortcomings in the existing laws and adequately implement the UN Trafficking Protocol. ${ }^{79}$

\section{Key Aspects of the Trafficking and Smuggling Proclamation}

As a specific law adopted to criminalize human trafficking, the Trafficking and Smuggling Proclamation is applicable at the federal level and in all regional states of Ethiopia. ${ }^{80}$ The Federal First Instance Courts are granted first instance jurisdiction to hear criminal cases involving human trafficking. ${ }^{81}$ For the purpose of avoiding confusion in the application of the Proclamation, it is expressly stated under Art. 48 that the Criminal Code articles that deal with human trafficking are repealed. ${ }^{82}$ It further provides that any law, regulation, directive or practice which is inconsistent with the Trafficking and Smuggling Proclamation shall not be applicable. ${ }^{83}$

Critical scrutiny of the contents of the Proclamation reveals that lawmakers have endeavored to mitigate the shortcomings of the existing legal framework on human

77 Mattar 2002, at 50.

78 As the upcoming discussions indicate, the Criminal Code and other laws do not address essential issues associated with human trafficking.

79 See para. 4 of the Preamble to the Trafficking and Smuggling Proclamation.

80 The FDRE Constitution establishes a federal form of government (Art. 1). In apportioning legislative power between the Federal government and regional States, Art. 55(5) provides that enacting criminal law is a power of the Federal government. Articles 243, 596, 597, 598, 599 and 635 of the Criminal Code that deal with human trafficking offenses have no more application, as they are repealed by the Proclamation (see Art. 48 of the Proclamation).

81 See Art. 24 of the Trafficking and Smuggling Proclamation.

82 Articles repealed in the Criminal Code are: Arts. 243, 596, 597, 598, 599 and 635.

83 See Art. 48(2) of the Trafficking and Smuggling Proclamation. The FDRE Constitution has succinctly stated under Art. 78 that until the establishment of federal courts in regional States, the jurisdiction of Federal First Instance Courts and High Courts is delegated to State courts. 
trafficking. Unlike previous laws of Ethiopia, the Proclamation gives due consideration to issues of prevention, protection, support and rehabilitation of victims of human trafficking ${ }^{84}$ This is made, as can be inferred from the Preamble of the Proclamation, through paying particular attention to the most vulnerable groups of society, taking into account their age, gender and special needs. ${ }^{85}$ Significant change is also made on the extent of punishment in respect of acts of human trafficking. Depending on the nature of harm inflicted on victims of the practice, courts can prescribe the death penalty for those convicted of involvement in human trafficking. ${ }^{86}$

The Proclamation is designed to apply to cases of human trafficking and the smuggling of migrants. It also regulates the conduct of criminals organized for trafficking and the smuggling of workers. ${ }^{87}$ As is widely held, trafficking in persons often occurs in connection with the movement of people from rural areas to urban areas or across international boundaries. ${ }^{88}$ On the other hand, this practice is mainly controlled and exploited by organized criminal groups. ${ }^{89}$ In view of this, placing the treatment of human trafficking, smuggling of workers and groups organized for trafficking and smuggling altogether in a single document appears plausible.

In the Proclamation, four key aspects are treated: i. Criminalization and Prosecution; ii. Prevention; iii. Protection, rehabilitation and compensation; and iv. Cooperation. The following section will critically assess the Criminalization and Prosecution aspect against international standards, particularly the UN Trafficking Protocol and the United Nations Convention against Transnational Organized Crime.

\subsection{Criminalization and Prosecution of Human Trafficking under the Trafficking and Smuggling Proclamation}

The Proclamation incorporates a number of provisions that facilitate the prosecution of human trafficking. Giving effect to the requirement of criminalizing human trafficking under the UN Trafficking Protocol, ${ }^{90}$ the Proclamation penalizes both "trafficking in persons" and "assisting and facilitating trafficking in persons."The definition of trafficking in persons can be inferred from Art. 3, which criminalizes the conduct:

84 See paras. 1 and 2 of the Preamble and Part Four, Five and Six of the Proclamation.

85 Para. 2 of the Trafficking and Smuggling Proclamation.

86 Read Arts. 3 and 6 of the Trafficking and Smuggling Proclamation.

87 See, e.g., Art. 6 of the Proclamation.

88 Economic and Social Commission, supra note 61, at 26. However, it should be underscored that movement of peoples is not an indispensable element of the definition of human trafficking under the UN Trafficking Protocol.

89

UNODC, Model Guide on Strengthening the Criminal Justice Response to Trafficking of Persons in the Black Sea Region (2009), at 17 (Sep. 4, 2017), available at https://www.unodc.org/documents/ human-trafficking/Model_Guide.pdf.

90 Art. 5 of the UN Trafficking Protocol. 
Any person, for the purpose of exploitation, within the territory or outside of Ethiopia:

a) at the pretext of domestic or overseas employment or sending to abroad for work or apprenticeship;

b) by concluding adoption agreement or at pretense of adoption; or

c) for any other purpose, using threat or force or other means of coercion, abduction, fraud, deception, promise, abuse of power or by using the vulnerability of a person or recruits, transports, transfer harbors or receives any person by giving or receiving payments or benefits to achieve the consent of a person having control over another person, shall be punishable with rigorous imprisonment from 15 years to 25 years and with fine from 150,000 to 300,000 birr.

The phrase "within the territory or outside of Ethiopia" in the above Article signifies that the Proclamation applies to both in-country trafficking and external trafficking.

As with the case in the UN Trafficking Protocol, the definition encompasses three elements: i. Act (recruitment, receipt, transport, transfer and harboring); ii. Means (force, deception, coercion, fraud, abuse of power or of a position of vulnerability payment or receipt of a benefit to a person with control of another); and iii. Purpose (exploitation). Article 2(4) has laid down that exploitation may include: "benefiting from prostitution of others or other forms of sexual exploitation,", "labor exploitation," "forced labor or servitude," "slavery or practices similar to slavery," "sexual servitude and enslavement," "debt bondage" or "surrender as pledge for another," "removal or taking of organs of the human body,"'forcefully engaging for begging" and "engaging children for military service. ${ }^{192}$ The listing is not exhaustive. ${ }^{93}$ Accordingly, other forms of exploitation that are not listed in the Article may be considered as important elements of the crime.

The above definition demonstrates that the Proclamation has incorporated almost all of the elements of the crime of human trafficking included under the UN Trafficking Protocol. Indeed, some important additions which are not mentioned under the Protocol are brought into the Proclamation. The Proclamation defines who

91 Although prostitution is not criminalized under the Criminal Code, a person will be held responsible under Art. 3 of the Proclamation if he benefits from the exploitation of the prostitution of others, provided other elements of the crime of human trafficking are fulfilled. The term "other forms of sexual exploitation" is also not defined in the Proclamation nor in any other international instrument. However, earlier drafts of the UN Trafficking Protocol defined it as practices which include: forced marriage, pornography and sex tourism (see Mattar 2002, at 725).

92 The Proclamation provides definitions for slavery (Art. 2(5)), servitude (Art. 2(6)) and debt bondage (Art. 2(7)).

93 Art. 2(4) reads: "Exploitation includes the following." 
"victims" are, ${ }^{94}$ potentially assisting in the assessment of compensation in addition to its use in the determination of penalties. ${ }^{95}$ Forceful engagement of individuals for begging and engaging children for military service are other modes of exploitation not listed under the Protocol. It seems to be that the phrase"Exploitation shall include, at a minimum..." found under the definitional provision of the Protocol (Art. 3) has guided the legislator to look for other potential instances of exploitation.

The issue of consent is adequately dealt with under the Proclamation. Article 14 unequivocally spells out that if the victim consents to the exploitation as a result of threat, coercion, other forms of coercion, abduction, fraud, deception, abuse of power or by using the vulnerability of the person or by giving or receiving bribe or benefits to achieve the consent of a person having control over another person, the criminal liability of the human trafficker will not be relieved. The consent of the victim will not exculpate the trafficker from criminal liability if the victim's consent is obtained through threat, coercion, abduction, etc. This indirectly means that the transaction would have been lawful if the abovementioned means had not been deployed. This is not the case insofar as children ${ }^{96}$ are concerned. The Proclamation provides that the consent given by a child or his guardian for human trafficking is unacceptable. ${ }^{97}$ Recruitment, transportation, transfer, harboring or receipt of children will be treated as trafficking in persons despite the means used are not those mentioned under Art. 3 (i.e. threat or force, abduction, coercion, etc.).

The special standard introduced in the Proclamation for children in dealing with consent conforms with the requirements of the UN Trafficking Protocol considered earlier and other international human rights instruments established for children such as the Convention on the Rights of the Child. As the UN Office of the High Commissioner for Human Rights (OHCHR) has elaborated, the particular physical, psychological and psychosocial harm suffered by trafficked children, and their increased vulnerability to exploitation, require that they be dealt with separately from trafficked adults in terms of laws, policies and programs. ${ }^{98}$ The best interests principle enshrined under the CRC requires that the laws adopted by States Parties

94 According to the Proclamation, only physical persons can be victims. Article 2(11) of the Proclamation defines victims as, "A person against whom the offence stipulated under the Proclamation has been committed or any person who has sustained harm, including mental and physical injury, emotional suffering, economic loss or substantial violation of basic human rights due to the commission of the crime."

95 In the determination of penalty, the number of victims involved results in the aggravation of penalty (see Art. 85 of the Criminal Code). Whenever compensation is determined, as can be noted from Art. 31 of the Proclamation, the court is expected to identify whether those individuals claiming to be victims fulfill the requisite elements of the definition produced above.

96 "Child" is defined under Art. 2(13) of the Proclamation as a person below the age of 18.

97 See Art. 14(2) of the Proclamation.

98 OHCHR, supra note 39 , at 64 . 
should promote the interests of children..$^{9}$ Owing to their immaturity, children may make decisions that run counter to their own interest. Relying on the consent that children give may end up in bringing prejudicial consequence on them.

Further endeavor has been made in the Proclamation to foster the protection of children and other vulnerable groups such as women and persons with disabilities. Article 3(2) prescribes more severe penalty for human trafficking perpetrated against such groups of people..$^{100} \mathrm{~A}$ similar approach is adhered to by a number of States Parties to the Protocol. ${ }^{101}$ The UN Trafficking Protocol is silent on the issue of whether States Parties should enshrine special punishment for crimes perpetrated against vulnerable groups of individuals.

This does not, however, render the Proclamation inconsistent with the Protocol. Indeed, rendering special protection to vulnerable groups such as women and children serves a twofold advantage: it will help to meet the objectives of the Protocol, which is combating human trafficking by paying particular attention to women and children, among others. Moreover, it will create favorable conditions for the government of Ethiopia to discharge its obligation of protecting the human rights of such groups of society emanating from international human rights treaties such as the CRC. It is important to stress that States Parties cannot neglect their existing obligations under international law, including international human rights law, in implementing the Protocol. ${ }^{102}$

Additional protection of the rights of children could have been offered if special provisions that criminalize promotion of child trafficking were included under the Proclamation. The Kenyan Counter-Trafficking in Persons Act (2012), for example, criminalizes acts that promote child trafficking. As enunciated under Art. 4, a person will be held criminally liable for promoting child trafficking if he, for the purpose of human trafficking: i. Adopts a child or offers a child for adoption; ii. Fosters a child or offers a child for fostering; or iii. Offers guardianship to a child or offers a child for guardianship. A person who initiates or attempts to initiate adoption, fostering or guardianship proceedings for the purpose human trafficking is likewise criminalized under this law. A provision with similar content is included under Sec. 6 of the Republic Act No. 9208 of the Philippines.

Following the guiding standards set forth under the UN Trafficking Protocol, the Proclamation criminalizes individuals who participate in human trafficking as an

99 Art. 3 of the CRC.

100 The crime entails a rigorous imprisonment of not less than 25 years or life imprisonment with fine from 200,000 to 500,000 birr.

101 In a number of State Parties to the UN Trafficking Protocol, the penalty for human trafficking becomes more severe if the crime is perpetrated against children. See, e.g., Art. 181 of the Criminal Code of Belarus, Art. 4 of the Counter-Trafficking in Persons Act of Kenya and Art. 4 of the Prevention of Trafficking in Persons Act of Uganda.

102 Read Art. 14 of the UN Trafficking Protocol. 
accomplice. ${ }^{103}$ As Art. 4 sets out, a person will be considered as an accomplice to the offense of human trafficking if he promotes the crime through performing any of the activities listed under the provision. ${ }^{104}$ The attempt to commit human trafficking is not criminalized under the Proclamation even though the UNTrafficking Protocol requires to this effect..$^{105}$ In fact, referring to the Criminal Code will be of great help in filling this lacuna since the general part of this law conveys that the attempt to commit an act criminalized under the laws of Ethiopia will entail criminal liability. ${ }^{106}$

One may note that the Proclamation failed to criminalize individuals who promote human trafficking by persuading other individuals, most notably women and children, to fall prey to traffickers. Research findings indicate that a number of individuals are lured to human trafficking as a result of strong pressure from friends, family and neighbors. ${ }^{107}$ Criminalizing such conduct of instigation may deter others from engaging in similar practices. ${ }^{108}$ Lessons may be drawn from other states, Israel for example, that have criminalized such acts. ${ }^{109}$ Perhaps, as criminal law penalizes individuals who intentionally or negligently become involved in criminal activities, it may be practically cumbersome to prove the presence of guilt in such particular circumstances. However, the special procedures that facilitate effective prosecution envisioned in the Proclamation can be used to mitigate this potential hindrance. ${ }^{110}$

As highlighted, the Proclamation has significantly increased the punishment for human trafficking. A number of States Parties to the UN Trafficking Protocol have also amended their criminal laws and changed the nature of punishment for human trafficking after ratifying the Protocol. ${ }^{111}$ Under the Proclamation, human trafficking is

103 Art. 5(2) of the UN Trafficking Protocol. The Proclamation also foresees the possibility that human trafficking may be committed by legal persons. Article 13 prescribes different amounts of fine taking into account the nature and degree of participation of legal persons in human trafficking.

104 These include: i. Permitting his house, building or other permits in his own name or in his control to be used for human trafficking; ii. Publishing, storing, disseminating, importing or exporting any publication; and iii. Managing, running or financing by organizing any job recruitment agency. to this particular case. This Article is only applicable to penalize individuals who persuade others to commit crime (including human trafficking). As such, it cannot be used to criminalize individuals who induce others to fall prey to traffickers.

109

110 The essential ones in this regard include those enshrined under Arts. 18, 21 and 23 that deal with "Special Investigation Techniques," "Burden of Proof" and "Suspects Immunity from Prosecution," respectively.

111 Read UNODC, supra note 48, at 55-56. 
a criminalized conduct which entails death, loss of liberty or fine depending on the nature of the case. The death penalty may be ordered if aggravating circumstances outlined under Art. 6 are fulfilled. However, one may discern that aggravating circumstances are not adequately dealt with under the Proclamation. The grounds listed under the Proclamation are not comprehensive. Unlike other jurisdictions, for example, the Proclamation has not explicitly stated whether exposing victims to HIV/AIDS or any other life-threatening disease can be considered an aggravating element. ${ }^{12}$

In fact, human trafficking which results in "physical or psychological harm" to the victim is considered as an aggravated offense under Art. 3(b) of the Proclamation. Nonetheless, this provision will not help to rectify the problem as it is too broad. Human trafficking generally, as considered earlier, entails both physical and psychological harm to victims. It is not clear whether courts should consider the extent of "physical or psychological harm" inflicted on victims in determining the gravity of the offense. Obsinan Girmaye, former Judge at Jimma High Court of Ethiopia, has explained that this broad provision creates difficulty in determining penalties. ${ }^{113}$

As with the case in the trafficking laws of the Republic of the Philippines and Uganda, it would have been appropriate if clear physical and psychological harm such as "insanity" and 'sustaining mutilation' were mentioned in the provisions. ${ }^{114}$ Moreover, the Proclamation considers human trafficking committed by public officials or civil servants as an aggravated charge if they commit the crime in their official capacity. The public prosecutor is expected to prove that the officials perpetrated the crime exceeding their power. This is a unique requirement when compared with other jurisdictions such as the Philippines and Uganda. ${ }^{115}$ Ostensibly, this will limit the scope of application of the provision and minimize the extent of protection of the Proclamation.

Under the Proclamation, any person who knows of the commission or preparation for the commission of human trafficking is duty bound to notify the police, any other relevant authority or local administrative organ and take other appropriate measures allowed by law. ${ }^{116}$ The previous laws that were in force did not impose a duty on individuals to report offenses of human trafficking. This new development might

112 See, e.g., Art. 4 of the Prevention of Trafficking in Persons Act of Uganda and Sec. 6 of the Republic Act No. 9208 - Anti-Trafficking in Persons Act of the Republic of the Philippines.

113 Interview with Obsinan Girmaye, former Judge, Jimma High Court of Ethiopia, in Jimma (15 July 2016). Obsinan suggested that the law should have clearly stipulated the degree of psychological and physical harm that makes an offense an aggravated one. In determining the severity of physical and psychological harm, he added, treating in-country trafficking and external trafficking will be of great significance since the consequences of the two forms of trafficking vary greatly.

114 See Art. 4 of the Prevention of Trafficking in Persons Act of Uganda and Sec. 6 of the Republic Act No. 9208 - Anti-Trafficking in Persons Act of the Republic of the Philippines.

115 The laws of such states qualify human trafficking committed by public officials or employees as an aggravating offense without considering whether the offense is committed in official capacity (see Art. 4 of the Prevention of Trafficking in Persons Act of Uganda and Sec. 6 of the Republic Act No. 9208 - Anti-Trafficking in Persons Act of the Republic of the Philippines).

116 Art. 16 of the Proclamation. 
have been made in response to the poor practice of reporting offenses of human trafficking in the years preceding the coming into force of the Proclamation. As the UNODC has disclosed, a total of 33, 16, 34 and 37 individuals were investigated for trafficking in persons in the years 2004, 2005, 2006 and 2007, respectively. ${ }^{117}$

Admittedly, fear of retaliation by traffickers discourages individuals from reporting trafficking offenses. Bearing this in mind, the anti-trafficking laws of some states protect the safety of those who report a trafficking crime. ${ }^{118}$ No such protection exists under the Proclamation. ${ }^{119}$

Additional provisions that promote the prosecution of human trafficking are included in the Proclamation. Article 10 of the instrument, for example, penalizes any person who intimidates or bribes an informant, witness or potential witness not to testify, to provide false testimony or conceal evidence in the process of criminal investigation, prosecution or court proceeding. On top of this, the Proclamation under Art. 11 criminalizes acts of concealing crimes of human trafficking and suspected criminals. According to this provision, concealing suspected criminals of human trafficking or hiding property used or planned for the commission of human trafficking may entail rigorous imprisonment from five years to ten years depending on the circumstances of the case.

Investigators are allowed to employ special investigative techniques when they reasonably suspect or believe that a crime of human trafficking has been, is being or is likely to be committed. ${ }^{20}$ These techniques include infiltrating suspected criminals, criminal groups or organizations, conducting surveillance against the suspects and intercepting private communications of the suspects by court order. ${ }^{121}$

Another important element of the Proclamation concerns the granting of immunity from prosecution. According to Art. 23 , any person involved in trafficking in persons crimes may be fully or partially freed from prosecution upon the decision given by the Minister if he/she provides substantial evidence as to the offense and other suspects before the case is taken to court. This procedure is in line with the UNTOC which requires States Parties to consider providing the possibility of granting immunity from prosecution to individuals who offer substantial cooperation in the investigation or prosecution of an offense covered under it. ${ }^{122}$

117 UNODC, Global Report on Trafficking in Persons (2009), at 113.

118 Art. 16 of the Legislative Decree No. 3 of 2010.

119 Perhaps Art. 29 ensures protection for victims who are witnesses of the crime of human trafficking. It does not provide protection for individuals who report the commission of human trafficking.

120 Art. 18 of the Proclamation.

121 Art. 18(1) of the Proclamation. Article 18(2) further provides that where there is a compelling condition and otherwise than intercepting the communications of the suspects, the police may intercept the communications of the suspects by the order of the Minister (Minister, as set out under the definitions part, is meant to refer to the Minister of the Ministry of Justice).

122 Close reading of Arts. 2, 3 and para. 1 of the Preamble reveals that human trafficking is among the offenses covered under the UNTOC. 
As can be discerned from Art. 21 of the Proclamation, the burden of proving criminal cases of human trafficking rests on the public prosecutor. In exceptional cases, however, the court may shift the burden of proof to the defendant if the public prosecutor proves fundamental facts. ${ }^{123}$ The Proclamation nowhere clarifies what fundamental facts are. It seems to be that the power to determine which facts are fundamental is granted to courts that entertain cases on human trafficking. If such courts consider fundamental facts as proven, they will shift the burden of proof to the defendant.

In its current form, this modality will undoubtedly undermine the defendants' ability to defend their case. It also violates the right to presumption of innocence of defendants guaranteed under the FDRE Constitution and other international human rights treaties ratified by Ethiopia such as the International Covenant on Civil and Political Rights (ICCPR). ${ }^{124}$ The UN Trafficking Protocol does not require States Parties to establish such a shift in the burden of proof. Earlier drafts of the UNTOC, however, provided instances when the burden of proof may be shifted to the defendant. ${ }^{125}$ This text was dropped after some delegations expressed concern that such a reversal might run counter to the defendant's right to presumption of innocence. ${ }^{126}$

As elaborated by Yibeltal Walelign, the above-considered elements of the Proclamation established to promote prosecution have not brought the intended result. ${ }^{127}$ Public prosecutors often face difficulty in proving human trafficking offenses to the required degree. ${ }^{128}$ This is, according to Walelign, partly caused by the complex nature of trafficking offenses. ${ }^{129}$ In Alemu Adero v. Federal Prosecutor, the defendant (Alemu Adero) was charged under the offense of human trafficking ${ }^{130}$ On 22 August 2015, Alemu Adero promised the victims (Alemnesh Alemu and Selam Tadiyos) to find them jobs in Beirut. He told them that he would complete the visa and other processes to enable them to lawfully enter Beirut and commence their work. To that end, he demanded advance payment as a service charge. Alemnesh Alemu did not agree to the amount requested. Subsequently, Alemu Adero was arrested by the police.

123 Art. 21(2) of the Proclamation.

124 See Art. 20 of the FDRE Constitution and Art. 14 of the ICCPR.

125 The draft provision on "Criminalization of Laundering of Proceeds of Crime" reads: "(a) A person convicted as a member of organized crime shall prove the legality of the purchase of goods that belong to him [or her] or in respect of which he [or she] acts as owner, otherwise they shall be confiscated" (UNODC, supra note 56 , at 48 and 53). See id.

Interview with Yibeltal Walelign, Coordinator of the Secretariat Office of the Anti-Human Trafficking and Smuggling of Migrants Task Force, Addis Ababa (13 September 2016).

See id.

See id.

Bezawit Kebede, Investigation and Prosecution of Transnational Human Trafficking in Ethiopia in Light of the International Legal System (May 2016) (unpublished MA thesis, Ethiopian Civil Service University) (on file with Ethiopian Civil Service University). 
The court found the defendant not guilty under the offense charged. As the judgment explains, neither the content of the charge nor the testimonies indicated whether the purpose of the transaction made between the defendant and the victims was for the purpose of exploitation. Similar decisions were made in other cases involving human trafficking. In Mohammed Gugsa v. Federal Prosecutor, the defendant was charged with facilitating human trafficking. ${ }^{131}$ The defendant was finally discharged since the public prosecutor failed to prove the purpose of the transaction concluded between him and the victims. ${ }^{132}$

These cases indicate that assessing other mechanisms that enhance effective prosecution are indispensable. To that purpose, it is generally submitted that improving the criminal justice system is imperative. As the UNODC underscored, without robust criminal justice response, human trafficking will remain a low-risk, high-profit activity for criminals. ${ }^{133}$ Darlene Reyes Pajarito has also suggested that ensuring protection to victims will help to mitigate the problems associated with prosecution of trafficking offenses. ${ }^{134}$ The contents of the Proclamation on protection of victims will be assessed in the upcoming section.

It is noteworthy that an endeavor to address human trafficking should not solely emphasize traffickers. The legal framework should be designed to account for the factors that promote human trafficking. It is well documented that the high demand for women and children for the sex industry, as cheap labor and as domestic workers is among the factors driving the continued trafficking of individuals. ${ }^{135}$ Given this reality, criminalizing traffickers only will not extinguish the problem. This issue is not properly dealt with in the UN Trafficking Protocol. Apart from stressing the importance of discouraging the demand that fosters human trafficking through legislative or other measures, the Protocol does not specifically require States Parties to criminalize demand drivers. This issue is properly considered in the Council of Europe Convention on Action against Trafficking in Human Beings, Art. 19:

Each State Party shall consider adopting such legislative and other measures as may be necessary to establish as criminal offences under its internal law, the use of services which are object of exploitation as referred to in Article 4 paragraph a of this convention with the knowledge that the person is a victim of trafficking in human beings.

131 See Kebede, supra note 130

132 See id.

133 UNODC, supra note 1 , at 1 .

134 Darlene Reyes Pajarito, Best Practices in the Protection, Prevention, and Prosecution of Human Trafficking Cases in Zamboanga City (Sep. 4, 2017), available at http://www.unafei.or.jp/english/pdf/RS_No87/ No87_14PA_Darlene.pdf.

135 Aiko Joshi, The Face of Human Trafficking, 13 Hastings Women's Law Journal 31, 35 (2002). 
While Ethiopia has not dealt with this matter in the Trafficking and Smuggling Proclamation, other states have in their legal acts. For example, in 2004, Croatia amended its criminal code to criminalize not only traffickers, but also clients of trafficked persons if they knew the victims had been trafficked. ${ }^{136}$ In the same vein, Syrian law explicitly states that anyone who has knowledge of the act of trafficking and benefits materially or morally from the services provided by the victim of trafficking shall be subject to imprisonment from six months to two years in addition to a fine. ${ }^{137}$

\section{Conclusion and Recommendations}

Human trafficking, which is dubbed "a contemporary form of slavery," is a global challenge entailing serious human rights violations on individuals, especially women and children. Authorities such as the UNODC and the International Labor Organization have held that no country is free from the problem. Ethiopia is no exception. Although the actual magnitude of human trafficking is unknown owing to the complexity and hidden nature of the problem, studies indicate that both external and in-country trafficking are pervasive in Ethiopia. The situation has driven the government to take measures aimed at helping to ameliorate the problem.

In 2012, the government of Ethiopia acceded to the UN Trafficking Protocol. To give effect to the requirements of the Protocol, the government has made efforts to incorporate the contents of the instrument in national laws. The Trafficking and Smuggling Proclamation was enacted to this effect. As noted in the discussion, the Proclamation contains four key aspects: i. Criminalization and Prosecution; ii. Prevention; iii. Protection, rehabilitation and compensation; and iv. Cooperation. The Proclamation underscores that paramount concern should be given to vulnerable groups of the society such as women and children in dealing with the abovementioned key aspects.

One of the obligations the UN Trafficking Protocol imposes on State Parties concerns criminalization of human trafficking. Art. 5 of the Protocol requires States Parties to criminalize "human trafficking" as defined in its text. As with the case in the UN Trafficking Protocol, the definition of human trafficking in the Proclamation contains three elements: i. Act (recruitment, receipt, transport, transfer and harboring); ii. Means (force, deception, coercion, fraud, abuse of power or of a position of vulnerability, payment or receipt of a benefit to a person with control of another); and iii. Purpose (exploitation). Illustrative mode of listing forms of exploitation is made in the Proclamation. Accordingly, in addition to forms of exploitation mentioned in the Proclamation such as sexual and labor exploitation, other forms of exploitation which are not explicitly enumerated may also be included.

\footnotetext{
136 UNODC, supra note 48, at 100.

137 Mattar 2002, at 116.
} 
The Proclamation criminalizes human trafficking under Art. 3. This in effect entails that all forms of exploitation covered by the definition are criminalized under the Proclamation provided that the remaining elements of the definition are present. Considering the special nature and vulnerabilities of children, the Proclamation, like the UN Trafficking Protocol, provides that the consent of a child given to traffickers will not have legal effect. In other words, traffickers will not be exonerated from criminal liability through proving that the victim child has given free and full consent. Moreover, one may note that trafficking in children, women or persons with mental or physical impairments will entail more severe penalty as compared to other cases.

The Proclamation prescribed more severe penalty for human trafficking as compared to previous laws. Depending on the circumstances of the case, human trafficking may entail life imprisonment or the death penalty. Both principal offenders and secondary participants who assist and facilitate trafficking in persons are criminalized under the Proclamation. Assistance and facilitation may include permitting a house, building, to be used for human trafficking, publishing, storing or disseminating publication, etc. Legal persons may also be held criminally liable under the Proclamation if they directly or indirectly participate in human trafficking.

The Proclamation criminalized some acts having the tendency to inhibit the effective prosecution of human trafficking offenses. "Concealing human trafficking offences and criminals involved in this crime" (Art. 11) and "failure to disclose criminal acts" (Art. 12) are criminalized in the Proclamation to encourage the reporting of human trafficking offenses. Other provisions of the Proclamation which criminalize producing, possessing, providing or transferring fraudulent or false identity cards (Art. 7), "destroying of evidence and blocking testimony" (Art. 10), and those dealing with "special investigative techniques" (Art. 18), "shift in the burden of proof" (Art. 21) and "immunity from prosecution" (Art. 23), on the other hand, are established to enhance effective investigation and prosecution of human trafficking.

In order to improve the effectiveness of the legal framework in addressing human trafficking, it is essential that the Criminalization and Prosecution aspect should be revisited to accommodate the following issues:

i. The legal framework, as observed in the discussions, fails to criminalize individuals who persuade others to fall prey to traffickers. Studies have found that significant numbers of individuals are lured into human trafficking due to pressure from friends, family and neighbors. Criminalizing such conduct may help to rescue potential victims. Some states, e.g. Israel, have criminalized such conduct. The government of Ethiopia should likewise consider criminalizing this conduct.

ii. In the Proclamation, human trafficking may be treated as an aggravated offense if victims sustain "physical and psychological harm." In reality, it is quite difficult to think of human trafficking which does not cause physical and psychological harm. Practice has also shown that it is challenging to identify human trafficking offenses which do not fall within this category. To do away with this confusion, it is important to indicate clear physical and psychological forms of harm, such as "insanity", in the provision. 
iii. In addition, human trafficking committed by public officials becomes an aggravated offense if it is committed in official capacity. In order to deter public officials from engaging in such practice, it is essential to consider human trafficking committed by public officials as an aggravated offense in all cases. This approach is practically followed in states such as Uganda and the Philippines. What is more, the Proclamation has not comprehensively dealt with aggravating circumstances. It is not clear, for example, whether exposing victims to HIV/AIDS or any other life-threatening disease can be considered as an aggravating circumstance. The government should consider including other aggravating elements in the provision.

iv. Under the Proclamation, everyone who knows of the commission of human trafficking is duty bound to report to the police or other relevant authority. The intended purpose of this requirement is to promote the reporting of human trafficking offenses. Nevertheless, the provision has not ensured protection to individuals who may suffer retaliation as a result of reporting. The government should establish mechanisms for providing protection to such individuals in order to achieve the underlying purpose of the provision.

v. As argued above, the criminalization of human trafficking should not merely target traffickers. In order to comprehensively deal with the problem, the demand that fosters human trafficking should also be analyzed. To this end, it is crucial that the Proclamation criminalize consumers who knowingly buy the services of trafficked persons.

vi. The Proclamation indicates that in exceptional cases the burden of proof may be shifted to the defendant if the public prosecutor proves fundamental facts. Understandably, this is intended to facilitate effective prosecution of human trafficking offenses. However, the Proclamation has not clarified what facts are fundamental. This standard is not stipulated in the UN Trafficking Protocol. It is clear that shifting the burden of proof will minimize the accused's ability to defend his case and violates his right to presumption of innocence guaranteed under international human rights instruments and the FDRE Constitution. In order to create conformity with international standards, the government should address this shortcoming through enabling the accused to properly defend his case.

\section{Acknowledgments}

The author gratefully acknowledges the endeavors Dr. Erica Harper made in editing and refining my work while supervising my LL.M. thesis work.

\section{References}

Beydoun K.A. The Trafficking of Ethiopian Domestic Workers into Lebanon: Navigating through a Novel Passage, 24(3) Berkeley Journal of International Law 1009 (2006). 
Gallagher A. Human Rights and the New UN Protocols on Trafficking and Migrant Smuggling: A Preliminary Analysis, 23 Human Rights Quarterly 975 (2001).

Joshi A. The Face of Human Trafficking, 13 Hastings Women's Law Journal 31 (2002). Manjoo R. Trafficking of Women: Norms, Realities, and Challenges, 7(1) Albany Government Law Review 5 (2014).

Mattar M.Y. Trafficking in Persons, Especially Women and Children, in Countries of the Middle East: The Scope of the Problem and the Appropriate Legislative Responses, 26 Fordham International Law Journal 721 (2002).

Schloenhardt A. \& Bevan E. To Ratify or Not to Ratify? Exploring the Barriers to Wider Ratification of the Trafficking in Persons Protocol, 9 New Zealand Yearbook of International Law 161 (2011).

Wakgari G. Causes and Consequences of Human Trafficking in Ethiopia: The Case of Women in the Middle East, 2(2) International Journal of Gender and Women's Studies 233 (2014).

\section{Information about the author}

Zelalem Shiferaw Woldemichael (Jimma, Ethiopia) - Lecturer of Law, Jimma University (Jimma University, P.O. Box 378, Jimma, Ethiopia; e-mail: zolalaw@gmail. com). 